\title{
OŚWIECENIOWY KANON LEKTUR I JEGO RECEPCJA WŚRÓD PŁOCKIEGO DUCHOWIEŃSTWA PARAFIALNEGO W CZASACH BISKUPA MICHAŁA JERZEGO PONIATOWSKIEGO ${ }^{1}$
}

\author{
Stanisław Witecki \\ Uniwersytet Jagielloński w Krakowie
}

\author{
ABSTRACT \\ THE ENLIGHTENMENT LITERARY CANON AND ITS RECEPTION \\ AMONG THE PARISH CLERGY IN THE DIOCESE OF PŁOCK \\ IN THE TIME OF BISHOP MICHAŁ JERZY PONIATOWSKI
}

Because of the priests' obligation to preach, teach catechisms, and hear confessions, books were essential in ministry. Bishops asked about them during visitations and sporadically recommended certain works, but it was not common to propose a comprehensive, coherent and well-designed set of obligatory reading for parsons. However, such an exceptional literary canon was created under the name of Bishop Michał Jerzy Poniatowski. The research problems of this article are the ideology of the proposed set of books and its reception among the parish clergy in the Diocese of Płock. I examined pastoral letters, recommended works and visitation protocols informing about book collections. As a result, I concluded that the canon represented the ideas of Catholic Enlightenment such as: orthodoxy, intellectualism, focus on morality, classicist style and rehabilitation of reason. However, the parish clergy accepted only practical and well-known genres regardless of stylistic and ideological novelty.

Key words: Enlightened Catholicism, literary canons, parish book collections, Diocese of Płock, $18^{\text {th }} \mathrm{c}$.

Słowa klucze: oświecony katolicyzm, kanon lektur, księgozbiory duchowieństwa parafialnego, diecezja płocka, XVIII w.

1 Badania prowadzone przy wsparciu finansowym MNiSW w ramach programu „Diamentowy Grant" (projekt nr DI2012018742).

Adres do korespondencji:stanislaw.witecki@gmail.com 


\section{WSTĘP}

Historiografia kultury europejskiego wieku XVIII to ciągłe próby odpowiedzi na dwa pytania: „czym było oświecenie?” oraz ,jaki był społeczny zasięg oświecenia?”2. Badacze dziejów XVIII-wiecznej Rzeczypospolitej, odpowiadając na pierwsze, podkreślają marginalność radykalnego oświecenia i dominację nurtu umiarkowanego, silnie powiązanego z katolicyzmem i często propagowanego przez przedstawicieli episkopatu ${ }^{3}$. Na drugie pytanie nie udzielono jeszcze pełnej odpowiedzi.

Prezentowany artykuł wpisuje się w badania nad stopniem i kierunkiem recepcji oświeceniowych reform biskupów wśród duchowieństwa parafialnego. Jest to problem istotny przynajmniej z dwóch względów. Po pierwsze, to plebani i wikariusze mieli regularny kontakt z wiernymi i mogli przekazywać idee mieszkańcom małych miast i wsi. Po drugie, treści głoszone przez biskupów bezpośrednio ich dotyczyły. Episkopat wypowiadał się na temat stylu życia, wykształcenia oraz obowiązków duszpasterskich ${ }^{4}$. Zarządcy parafii oraz ich pomocnicy musieli więc świadomie ustosunkować się do płynących z góry zarządzeń.

Jan Kracik podkreślał nikły wpływ centralnych i teoretycznych projektów biskupich na praktykę życia parafialnego ${ }^{5}$. Rzecz jasna, nie można wyciągać wniosków na temat realiów na podstawie źródeł normatywnych. Nie powinno się jednak również a priori negować wpływu, jaki miały na plebanów narzucone pod groźbą kar biskupie zalecenia. Stoję na stanowisku, że konieczne są szczegółowe badania poświęcone recepcji rozporządzeń każdego biskupa przez duchowieństwo jego diecezji. Poszczególni ordynariusze oraz ich współpracownicy różnili się bowiem zarówno wyznawaną ideologią, jak i metodami, za pomocą których starali się ją propagować ${ }^{6}$.

Niniejszy artykuł dotyczy stworzonego pod egidą biskupa Michała Jerzego Poniatowskiego programu, przedstawionego duchowieństwu diecezji płockiej w trakcie

2 R. Darnton, In Search of the Enlightenment: Recent Attempts to Create a Social History of Ideas, „The Journal of Modern History” 1971, t. 43, nr 1, s. 113-132.

3 R. Butterwick, Między oświeceniem a katolicyzmem, czyli o katolickim oświeceniu i oświeconym katolicyzmie, „Wiek Oświecenia” 2014, t. 30, s. 11-55; R. Szczurowski, Zaradzić potrzebom doczesnym i wiecznym. Idee oświecenia w Kościele katolickim w Polsce (do 1795 r.), Kraków 2014; J. Kracik, Ewangelicznie i rozumnie. Oświecenie katolickie, „Znak” 1992, nr 451, s. 57-69.

${ }_{4}$ M. Ślusarska, Oświeceniowe modele biskupa, plebana i parafii. Kontynuacja czy zmiana tradycji? [w:] Dwór-plebania-rodzina chlopska. Szkice z dziejów wsi polskiej XVII i XVIII wieku, Warszawa 1998, s. 37-53; R. Szczurowski, Pastoralny i literacki wzorzec kapłana doby oświecenia [w:] Historia bliższa ludziom. Prace ofiarowane Księdzu Profesorowi Janowi Kracikowi w 70. rocznice urodzin, red. R. Szczurowski, E.E. Wróbel, Kraków 2011, s. 333-346.

5 J. Kracik, Vix venerabiles. $Z$ dziejów społecznych niższego kleru parafialnego w archidiakonacie krakowskim XVII-XVIII w., Kraków 1982.

${ }_{6}$ Brakuje pracy porównawczej, ale o różnicach między programami można się przekonać w trakcie lektury monografii poszczególnych biskupów. W monografii tematu autor nie szukał cech charakterystycznych, skupiając na wspólnych trendach, R. Szczurowski, Zaradzić potrzebom doczesnym i wiecznym..., passim; T. Kasabuła, Ignacy Massalski biskup wileński, Lublin 1998; M. Grzybowski, Kościelna działalność Michała Jerzego Poniatowskiego biskupa płockiego 1773-1785, Warszawa 1983. 
pontyfikatu hierarchy, przypadającego na lata $1773-1781^{7}$. Wspomniany program zasługuje na szczególną uwagę, ponieważ dołożono wszelkich starań, aby został wdrożony, a więc można się spodziewać, że jego recepcja była duża. Szczegółowym przedmiotem badawczym uczyniłem kanon lektur, który miał służyć samokształceniu duchowieństwa. Dwoma podstawowymi celami tego artykułu są rekonstrukcja zawartej w programie ideologii oraz zbadanie stopnia jej akceptacji przez zarządców parafii ${ }^{8}$.

\section{METODA I ŹRÓDŁA}

Problem recepcji jest ciekawy ze względu na różnice między celami autorów rozporządzeń a potrzebami ich adresatów. Ich rozbieżność wynikała z przepaści, jaka dzieliła środowisko biskupa i jego współpracowników od rezydujących i niekumulujących beneficjów plebanów wiejskich oraz małomiasteczkowych parafii ${ }^{9}$. W artykule interpretuję kierunkowo ograniczoną recepcję kanonu lektur przez pryzmat różnic społeczno-kulturowych.

Pojęcia „recepcja” używam w znaczeniu świadomych decyzji o przyjęciu lub odrzuceniu narzucanych z zewnątrz treści w zależności od osobistych potrzeb i preferencji ideowych członków określonej grupy społecznej. Definicja ta wynika z inspiracji pracami głoszącymi przekonanie o autonomiczności kultur poszczególnych grup społecznych i propagującymi badania ich wzajemnego wpływu ${ }^{10}$. Komunikacja między kurią a duchowieństwem parafialnym była dwustronna, ale nierówna. Rozporządzenia biskupa i jego współpracowników miały rangę obowiązującego prawa, a ich autorzy mogli się stawiać w pozycji autorytetów reformujących niespełniające ich wymagań duchowieństwo parafialne. Plebani i wikariusze nie przyjmowali

7 M. Grzybowski, Formacja intelektualna i moralna duchowieństwa diecezji płockiej $w$ czasach rzadów bp M.H. Poniatowskiego (1773-1785), „Studia Płockie” 1976, t. 4, s. 77-100; idem, Życie religijno-moralne $w$ diecezji płockiej $w$ czasach rządów biskupa M.J. Poniatowskiego (1773-1785), „Studia Płockie” 1976, t. 4, s. 101-144; idem, Reforma studiów seminaryjnych w diecezji płockiej biskupa Michała Jerzego Poniatowskiego (1773-1785), „Studia Płockie” 1973, t. 1, nr 175-193.

8 Kanon lektur zauważono, ale nie podjęto jego szerszej interpretacji. Recepcję zbadano na niepełnym materialne źródłowym i wyłącznie w kategoriach ilościowych, D. Główka, Księgozbiory duchowieństwa płockiego w XVIII wieku, „Kwartalnik Historyczny” 1995, t. 52, nr 2, s. 18-19.

9 T. Wiślicz, Shepherds of the Catholic Flock: Polish Parochial Clergy, Popular Religion, and the Reception of the Council of Trent [w:] Gelehrte Geistlichkeit - geistliche Gelehrte. Beiträge zur Geschichte des Bürgertums in der Frühneuzeit, t. 97: Historische Forschungen, red. L. Schorn-Schütte, Berlin 2012, s. 25-52; idem, Jak gdyby wśród pogan lub heretyków. Polityka potrydenckiego Kościoła wobec religii ludowej i jej osobliwości w Rzeczypospolitej [w:] Staropolski ogląd świata. Rzeczypospolita między okcydentalizmem a orientalizacja. Przestrzeń wyobrażeń, t. 2, red. R. Kołodziej, F. Wolański, Toruń 2009, s. 31-42.

10 P. Burke, Kultura ludowa we wczesnonowożytnej Europie, thum. R. Pucek, M. Szczubiałka, Warszawa 2009, s. 46-108; C. Giznburg, Ser i robaki. Wizja świata pewnego mlynarza z XVI w., tłum. R. Kłos, Warszawa 1989, s. 7-24. 
jednak wszystkich narzucanych przez administrację treści i nie ukrywali tego faktu w przedstawianych wizytatorom protokołach. Ignorowali szczególnie te komunikaty, które traktowali jako kłopotliwe zarządzenia administracyjne, wykazujące ponadto nieznajomość ich realiów życia. W związku z tym nie uważam oświeconych, w mniemaniu twórców, reform za probierz postępu, a ich odrzucenia za oznakę zacofania. Spoglądam na recepcję kurialnych zarządzeń jako na starcie poglądów dwóch grup równych kulturowo, ale nierównych statusem i władzą.

$\mathrm{Z}$ powyższych rozważań wypływają konkretne konsekwencje metodologiczne. Konieczna była szczegółowa interpretacja kanonu lektur traktowanego jako tekst mający swoje autonomiczne znaczenie i profil ideologiczny. Wychodziłem z założenia, że najistotniejszy był dobór tytułów i gatunków, a nie dokładna treść każdego dzieła. W związku z tym nie omawiam osobno każdej książki, ale przedstawiam wnioski na temat znaczenia całego kanonu. Przeciwna strategia skazywałaby na nieuchronne powtórzenia i oddalała uwagę od łączących rekomendowane pozycje cech wspólnych. Niemniej prezentowane wnioski są oparte na lekturze tych książek, które na drodze przeprowadzonych badań wytypowałem jako najczęściej czytane przez plebanów, oraz na lekturze funkcjonujących w literaturze przedmiotu opracowań pozostałych dzieł. Ze względu na klarowność narracji i oszczędność miejsca nie przytaczam za każdym razem tytułów i autorów książek. W zamian stosuję przypisy składające się $\mathrm{z}$ liczb porządkowych poszczególnych pozycji kanonu zaprezentowanych $\mathrm{w}$ aneksie zawierającym pełne opisy bibliograficzne oraz odnośników do opracowań na ich temat uwiarygadniających moje interpretacje.

Kanon lektur stanowił centralny element programu, który Zofia Zielińska nazwała „permanentnym kształceniem duchowieństwa”"11. Pojawiał się on w kontekście reformy seminarium ${ }^{12}$, misji parafialnych ${ }^{13}$, w powizytacyjnej ewaluacji diecezji ${ }^{14}$ oraz - przede wszystkim - w długim liście pasterskim prezentującym zasady samokształcenia $^{15}$. Jego kształt odtwarzam na podstawie propozycji zawartej w liście pasterskim z 20 sierpnia $1775 \mathrm{r} .{ }^{16}$ Stanowiła ona część dłuższej wypowiedzi wyczerpująco uzasadniającej pożytki płynące z nauki poszczególnych dyscyplin wiedzy. Pozostałe propozycje były znacznie krótsze, wtórne i pozbawione komentarza. Interpretacje opieram więc nie tylko na doborze polecanych dzieł, ale również na przedstawionych plebanom racjach stojących za ich rekomendacją.

Nie interesowała mnie natomiast biograficzna geneza ideologii. Ostatecznie dla plebanów decydujących o wdrożeniu kanonu nie miały żadnego znaczenia powody

11 Z. Zielińska, Michat Jerzy Poniatowski h. Ciołek [w:] Polski Stownik Biograficzny [dalej: PSB], t. 17, red. B. Leśnodorski, Wrocław-Warszawa-Kraków-Gdańsk 1972, http://www.ipsb.nina.gov.p1/ index.php/a/michal-jerzy-poniatowski-h-ciolek [dostęp: 8.12.2016].

12 M. Grzybowski, Reforma studiów..., s. 180-186.

${ }_{13}$ M. Poniatow ski, Rozrządzenia y pisma pasterskie za rządów J.O. Xięcia JMCI Michała Jerzego Poniatowskiego Biskupa Ptockiego do diecezyi płockiey wydane dla wygody teyże Dyecezyi zebrane, i do Druku podane [dalej: Rozrządzenia ...], t. 3, Warszawa 1785, s. 168-294.

14 Ibidem, s. 5-6.

15 Rozrzadzenia..., t. 1, s. 406-426.

16 Ibidem, s. 391-589. 
jego powstania. $Z$ ewentualnym powoływaniem się na życiorysy twórców wiązałby się zresztą dodatkowy problem badawczy. Mianowicie nie można z całkowitą pewnością ustalić jego autorstwa. Stanowi co prawda część podpisanego przez biskupa Michała Jerzego Poniatowskiego listu pasterskiego, był więc przez niego przynajmniej akceptowany, ale ks. Michał Grzybowski, idąc za uwagami ks. Stefana Biskupskiego, przypisuje autorstwo rozrządzeń pasterskich audytorowi i generalnemu sędziemu diecezji ks. Krzysztofowi Żurawskiemu. W niniejszym tekście przyjmuję więc autora hipotetycznego, czyli biskupa i jego współpracowników, za istotny uznając jedynie fakt, że byli to wykształceni przedstawiciele elity przebywający w Warszawie ${ }^{17}$.

Za miarę recepcji kanonu przyjąłem liczbę egzemplarzy danego dzieła we wszystkich zbadanych księgozbiorach będących w dyspozycji plebanów diecezji płockiej, z wyłączeniem kolekcji książek katedralnych, kolegiackich i zakonnych. W celu odróżnienia dzieła odziedziczonego od poprzedników od nowo zakupionych konieczne okazało się również zebranie informacji na temat sposobu użytkowania, stosunku plebanów do książek oraz przynależności do kolekcji prywatnych bądź plebańskich ${ }^{18}$. Wszystkie te dane zawierały 192 protokoły wizytacji przeprowadzanych w latach $1775-1776$ oraz $1781^{19}$, na podstawie punktów wydanych 8 marca $1775^{20}$. W całej diecezji w 1772 roku było 300 parafiii ${ }^{21}$, a do dzisiaj zachowały się protokoły 262. Część z nich nie zawierała jednak indeksów księgozbiorów.

Pozostaje jeszcze problem przydatności i wiarygodności źródeł o charakterze administracyjno-sprawozdawczym do badania praktyki życia. Oczywiście wypełniający ankiety plebani kształtowali obraz swojej pracy tak, by zadowolić przełożonych. Mogli więc pisać, że czytają książki, podczas gdy dokonywali ich zakupu wyłącznie po to, aby postawić je na półce. Istnieje też możliwość, że ukrywali dzieła niepolecane $\mathrm{w}$ liście pasterskim, a w szczególności te zakazane ${ }^{22}$. Z pewnością jednak deklaracja posiadania danej książki była zgodna z rzeczywistością. Dotyczy to przede wszystkim publikacji rekomendowanych, ale nie tylko. Ankiety kontrolowali wizytatorzy sprawdzający cały majątek parafialny. W latach $1774-1776$ byli to duchowni wyznaczeni przez kurię, a w 1781 - lokalni dziekani ${ }^{23}$. Mimo istniejącej możliwości plebani nie ukrywali jednak faktu czytania wielu książek niepolecanych

17 M. Grzybowski, Kościelna działalność Michała Jerzego Poniatowskiego..., s. 35-42.

18 J. Kracik, Biblioteka parafialna a prywatne księgozbiory duchowieństwa. Dekanat Nowa Góra w XVII-XVIII wieku, „Archiwa, Biblioteki i Muzea Kościelne” 1976, t. 32, s. 249-271.

19 Większość zachowanych protokołów wizytacji diecezji płockiej z lat 1775-1781 została wydana drukiem, Materiaty do dziejów ziemi płockiej. Z archiwaliów diecezjalnych płockich XVIII wieku, t. 1-15, red. M. Grzybow ski, Płock 1981-2012. Ze względu na niedostępność t. 12 i 13 przebadałem oryginały w Archiwum Diecezjalnym w Płocku: Wizytacja dekanatu płockiego 1774 r., AV 288; Wizytacja dekanatów: Ostrołęka, Ostrów, Wąsocz, Wizna, Wyszków 1774 r., AV 307. Wszystkie informacje odnoszące się do zawartości księgozbiorów parafialnych zostały oparte na analizie statystycznej tych materiałów.

20 Rozrzadzenia..., t. 1, s. 292-337.

21 S. Litak, Kościót taciński w Polsce około 1772 roku: mapa - komentarz - indeks, Lublin 1991, s. 261-277.

22 Rozrządzenia..., t. 1, s. 463.

23 M. Grzybowski, Kościelna działalność Michała Jerzego Poniatowskiego..., s. 74-76. 
przez biskupa. Krótko mówiąc, zarządcy parafii na pewno posiadali te książki, które wykazali, a spośród książek rekomendowanych mieli wyłącznie te, które wymienili.

Interpretacja kanonu lektur i książek posiadanych przez plebanów musiała zostać poprzedzona żmudną pracą przygotowawczą, czyli identyfikacją polecanych dzieł. Ani autorzy listu pasterskiego, ani duchowni sporządzający protokoły wizytacyjne nie posługiwali się profesjonalnym opisem bibliograficznym, lecz różnego typu skrótowymi zapisami. Problemy wiążące się z identyfikacją książek wymienionych w tego typu źródłach zostały już opisane ${ }^{24}$. Chciałbym tylko wskazać, że wykaz książek posiadanych przez plebanów opracowałem za pomocą bazy danych i udostępniłem online na stronie http://ksiegozbioryparafialne.omnino.com.pl/. Listę książek rekomendowanych zamieściłem z kolei w aneksie niniejszego artykułu.

\section{PROFIL IDEOWY KANONU LEKTUR}

Dołożono wszelkich starań, aby kanon lektur przygotowany przez administrację biskupa Poniatowskiego został rozpowszechniony. Obowiązek jego przyjęcia wzmocniono nie tylko groźbą dotkliwych kar, ale także obietnicą prestiżowej nagrody. Dziekanów zobowiązano do odczytywania listów pasterskich w czasie odbywających się dwa razy w roku kongregacji dekanalnych. Dawało to gwarancję dotarcia do adresatów, zwłaszcza że dziekani mieli prawo do karania grzywną nieobecnych, a nawet do suspendowania najbardziej niepokornych księży. Co więcej, plebanów zobowiązano do publicznego odczytywania rozprawek teologicznych, na zadany przez profesorów seminaryjnych temat, $\mathrm{w}$ trakcie kongregacji dekanalnych ${ }^{25}$. Obawa przed publicznym skompromitowaniem się przed resztą duchowieństwa mogła być silnym bodźcem do zakupu stosownych książek i przyswojenia sobie ich treści ${ }^{26}$. Wreszcie pomyślano o nagrodzie dla najbardziej gorliwych w nauce księży. Najlepsze teksty składane dwa razy do roku do warszawskiej kancelarii zadwornej wydano drukiem ${ }^{27}$.

Kanon lektur składał się z 66 dzieł 55 autorów. Publikacje podzielono na 10 kategorii niedających się sprowadzić do funkcjonujących we współczesnej literaturze gatunków. Przykładowo podzielono homiletykę na trzy osobne kategorie, czyli kazania stare, nowe i podręczniki kaznodziejskie, oraz potraktowano oddzielnie katechizmy i podręczniki teologiczne. Pozostałe rekomendowane książki zaklasyfikowano do:

24 J. Szady, Księgozbiory parafialne $w$ prepozyturze wiślickiej $w$ drugiej połowie XVIII wieku, Lublin 2008, s. 53-58; S. Wite cki, Oświecony katolicyzm trydencki. Księgozbiory duchowieństwa parafialnego diecezji płockiej w okresie pontyfikatu bp Michała Jerzego Poniatowskiego, „Wiek Oświecenia” [w druku].

25 M. Grzybowski, Formacja intelektualna ..., s. 85-90.

26 J. Kracik, Biblioteka parafialna..., s. 267-268.

27 Kazania niektóre Księży Diecezji Ptockiej z podanych co rocznie dwiema ratami w Maju i w Październiku do Kancelarji Zadwornej Biskupiej 1782. Teraz z tejże Kacelarji wydane i do druku podane 1785, bmw, 1785. 
teologii dogmatycznej (w istocie były do wyłącznie dzieła z zakresu teologii moralnej), historii kościelnej, prawa kanonicznego, liturgiki, biblistyki i ascetyki ${ }^{28}$.

Przygotowując listę lektur, administracja nie miała wglądu w stan księgozbiorów parafialnych ${ }^{29}$. Dobór książek był więc niezależny od aktualnej kultury książki i arbitralnie narzucano te dzieła, które uznano za stosowne. Nie liczono się ze stanem posiadania plebanów, ale racjonalnie oceniono szansę nabycia nowych dzieł. W większości kategorii wyróżniono jednego lub dwóch autorów, których książki były lepiej rozpoznawalne oraz łatwiej dostępne na polskim rynku i rekomendowano ich nabycie w pierwszej kolejności.

\section{ROZSZERZENIE ZESTAWU GATUNKÓW RELIGIJNYCH}

Książki na liście miały charakter wyłącznie religijny. Nie znalazły się na niej dzieła z zakresu historii narodowej, filozofii czy literatury pięknej. Nie byłoby w tym może nic dziwnego, gdyby twórcy kanonu nie pisali o wartości świeckiej wiedzy. Wskazywali oni nie tylko na jej praktyczną użyteczność, ale także na konieczność, by nie odstawać kulturowo od lokalnego szlacheckiego towarzystwa:

Od wszystkich na koniec choć obojętnych ale bardzo człowieka zdobiących nauk, żądamy z powtórzeniem, aby kapłani wstrętu nie mieli i one lekce nie ważyli, już dla poradzenia drugim, co komu według jego stanu służyć może, już dla mówienia o nich, kiedy się do tego okazja poda, i gdzieby ich milczenie dowodem było nagannej onychże nieumiejętności, przyczyną wzgardy oraz początkiem od nich się, jako od mniej oświeconych ludzi odrażenia i żeby jako się od pospolitych ludzi zacnością powołania różnią, tak różnili i przez dowody właściwe, to jest wszelkiego rodzaju wiadomościami ${ }^{30}$.

Wydaje się, że o charakterze ideowym programu lepiej świadczy wprowadzana konsekwentnie wyłącznie lista religijnych lektur niż wyżej zacytowane, niepoparte konkretami podkreślanie przydatności wiedzy świeckiej. W przeciągu pontyfikatu Poniatowskiego polecono tylko przyrodnicze dzieło pijara Józefa Osińskiego Sposób ubespieczaiacy życie y majątek od piorunów... (Warszawa 1784) (11 $^{31}$ oraz racjonalistyczny traktat Jana Bohomolca Diabet w swoiey postaci... (Warszawa 1775), ale czyniono to bez związku z systemem kształcenia duchowieństwa ${ }^{32}$.

${ }^{28}$ W opisie części składowych kanonu powołuję się na tabelę zamieszczoną w aneksie. Jeżeli odwołuję się do konkretnego dzieła, w nawiasie podaję numer porządkowy do niego przypisany.

${ }_{29}$ Tylko w dwóch dekanatach wizytacje rozpoczęły się przed wydaniem listu pasterskiego - szreńskim (od 5 VI 1775 do 6 I 1776) oraz górzeńskim (od 30 V 1775 do 22 XII 1775). Zachowała się tylko część protokołów tej wizytacji, M. Grzybowski, Kościelna działalność Michała Jerzego Poniatowskiego..., s. 82-89.

30 Rozrzadzenia..., t. 1, s. 424.

31 Bibliografia Polska Karola Estreichera [dalej: Estreicher], http://www.estreicher.uj.edu.pl/staropolska/ [dostęp: 18.03.2016] , cz. 3, t. 12, s. 465, Rozrządzenia..., t. 4, s. 183-187.

${ }_{32}$ Rozrzqdzenia..., t. 3, s. 120; R. Butterwick, Polska rewolucja a kościót katolicki 1788-1792, thum. M. Ugniewski, Kraków 2012, s. 177; M. Grzybowski, Kościelna działalność Michała Jerzego Poniatowskiego..., s. 158. 
Kanon lektur był wprawdzie wyłącznie religijny, ale wykraczał daleko poza dotychczasowe przyzwyczajenia gatunkowe duchowieństwa, ograniczające się do homiletyki, katechetyki i teologii moralnej ${ }^{33}$. Do dzieł o charakterze praktycznym, służących wypełnianiu elementarnych obowiązków plebańskich, dołożono dzieła thumaczące sens przeprowadzonych ceremonii (liturgika), przywracające centralną rolę Biblii i konieczności jej zrozumienia (biblistyka), przedstawiające dziejową misję Kościoła (historia) oraz precyzyjnie określające powinność duchownego wobec przełożonych i relację między stanem duchownym a wiernymi (prawo kanoniczne). Krótko mówiąc, do praktyki dodawano teorię, a do świadomości zawodowej - świadomość stanową. Ponadto propagowano teologię ascetyczną, co wraz z reformą rekolekcjii miało rozwinąć osobistą pobożność duchowieństwa wykraczającą poza pilne sprawowanie obowiązkowych rytuałów.

\section{KATOLICKA PRAWOWIERNOŚĆ}

Reformatorskość tego programu nie powinna być jednak mylona z podważaniem jakichkolwiek zasad katolickich. Poniatowski i współpracownicy zwalczali bowiem raczej barokową praktykę niż trydencką teorię, a troska o prawowierność była widoczna nieomal w każdym elemencie kanonu. Najbardziej objawiała się przez uczynienie Benedykta XIV najczęściej rekomendowanym autorem $\left(3.6,3.7,4.3,9.3^{35}\right)$ oraz dobór książek cieszących się poparciem bądź przynajmniej akceptacją Stolicy Apostolskiej $\left(1.2,2.1,2.3^{36}\right.$ ). Co ciekawe, sam Michał Poniatowski był zwolennikiem dużej niezależności biskupów lokalnych od papieża ${ }^{37}$, ale najwidoczniej czym innym były kwestie administracyjne, a czym innym dogmatyczne.

Przywiązanie do ortodoksji widać również w trosce o wynikającą ze statutów soboru trydenckiego znajomość obowiązków administracyjnych i kapłańskich. W związku z tym poczesne miejsce przyznano prawu kanonicznemu, które ogłoszono drugą najważniejszą dyscypliną po teologii. Wymagano od plebanów jej doskonałej znajomości, ale bez zagłębiania się w teorię i bez konieczności rozeznania

33 J. Kracik, Biblioteka parafialna ..., s. 249-271; K.M. Kowalski, Ksiegozbiory parafialne archidiakonatu pomorskiego w XVI-XVIII [w:] Studium z dziejów kultury intelektualnej Prus Królewskich, Gdańsk 1993; T. Moskal, Biblioteki parafialne w archidiakonacie sandomierskim w XVIII w., Sandomierz 2005; J. Szady, op. cit., passim; S. Witecki, op. cit., passim.

34 M. Grzybowski, Formacja intelektualna ..., s. 82-85.

$35 \mathrm{~W}$ nawiasach podaję numery, które w aneksie przypisałem każdej pozycji kanonu.

36 T. Obłąk, Gabriel Paul Antoine [w:] Encyklopedia katolicka, t. 1, red. F. Gryglewicz, R. Łukaszyk, Z. Sułowski, Lublin 1973, s. 655; N.A. Weber, Giovanni Lorenzo Berti [w:] Catholic Encyclopedia [dalej: CE], t. 2, New York, https://en.wikisource.org/wiki/Catholic_Encyclopedia_(1913) [dostęp: 18.03.2016]; A.L. McMahon, Alexander Natalis, CE, t. 1.

37 A. Sołtys, Powiernik, przyjaciel, sprzymierzeniec, ,, aktor” drugiego planu-prymas Michat Jerzy Poniatowski [w:] Pamiętniki Stanistawa Augusta i ich bohaterowie, red. A. Grześkowiak-Krwawicz, Warszawa 2015, s. 151-152. 
w sposobach prowadzenia procesu. Celem nauki było poprawne orzekanie w sytuacji, gdy pleban pełnił funkcję sędziego (zarówno sumień, jak i poddanych), ale przede wszystkim doskonała znajomość własnych powinności wobec przełożonych kościelnych $^{38}$. Autor jednej z polecanych książek konsekwentnie bronił prymatu katolicyzmu oraz propagował pogląd o nieomylności biskupa Rzymu $\left(3.1^{39}\right)$. Legalistyczny zestaw lektur uzupełniono zbiorem aktów prawnych archidiecezji gnieźnieńskiej oraz statutem ostatniego synodu płockiego $\left(3.3,3.4^{40}\right)$.

Bezpośrednio $\mathrm{z}$ ustaw soborowych wynikała też dbałość o poziom ceremonii kościelnych. Reformy Poniatowskiego kojarzone są przede wszystkim z walką z ludową paraliturgią, w tym szczególnie z jasełkami bożonarodzeniowymi i biczowaniem wielkopostnym ${ }^{41}$, ale $\mathrm{w}$ programie samokształcenia skupiono się na problemach podstawowych. Nakazywano zakup mszałów i brewiarzy, a tam, gdzie to konieczne: antyfonarzy, graduałów, rytuałów i agend. Wizytatorzy mieli sprawdzać aktualność i stan materialny tych ksiąg oraz donosić o wszelkich uchybieniach. Wyrażano wyłącznie życzenie, by „nie przypadkiem, nie z domysłu, nie zgrubemi częstokroć omyłkami czyni co kapłan, ale z wiadomością najdrobniejszych rzeczy, które mu się przepisują..." ${ }^{\prime 2}$.

Wreszcie przywiązanie do katolickiej ortodoksji widać w podejściu do historii kościelnej, która miała pełnić funkcję zbioru godnych naśladowania przykładów, dowodu na nieulegający trudnościom postęp wiary ${ }^{43}$ oraz uzasadnienia należnego religii autorytetu ${ }^{44}$. Treść części podręczników wpisywała się wręcz w schemat kontrreformacyjny $\left(2.4,2.5,2.7^{45}\right)$. Kontrastowało to $\mathrm{z}$ instrukcją nauczania na katolickich uniwersytetach niemieckich, wydaną w tym samym roku przez Stefana Reutenstracha, w której historia miała służyć celom praktycznym, na przykład rozdziałowi kompetencji władzy duchowej i świeckiej. Nie miało też nic wspólnego z przeprowadzanymi w tym samym czasie reformami józefińskimi. Cesarz austriacki, przekraczając bariery konfesyjne, zaproponował bowiem protestancki podręcznik Schrocka, który wycofał dopiero z powodu sprzeciwu arcybiskupa Wiednia. W poglądach na temat historii kościelnej program wprowadzony pod egidą biskupa Poniatowskiego można więc uznać nie tylko za ortodoksyjny, ale również za konserwatywny. XVIII wiek był bowiem przełomowy w historii historiografii kościelnej. Po raz pierwszy napisano wtedy dzieła, których przedmiotem nie była historia Zbawienia, celem - apologia chrześcijaństwa, a jedynym czynnikiem sprawczym dziejów - wola

38 Rozrzadzenia..., t. 1, s. 412-414.

39 W.H. Windsor Fanning, Vitus Pichler, CE, t. 12.

40 Estreicher [dostęp: 18.03.2016]; Rozrzadzenia ..., t. 1, s. 214.

41 R. Szczurowski, Zaradzić potrzebom..., s. 56-58.

42 Rozrzadzenia..., t. 1, s. 418.

43 Kontrastowało to z protestancką historiografią, która podkreślała, że Kościół przeżywał kryzys, z którego wyprowadziła go reformacja, zob. G. Romuald, Rozwój pojęcia historii kościoła, Poznań 1964, s. 69-74.

44 Rozrzadzenia..., t. 1, s. 411-412.

45 F. Vannini, Mario Guarnacci [w:] Dizionario Biografico degli Italiani, t. 60, 2003, http://www. treccani.it/enciclopedia/mario-guarnacci_(Dizionario-Biografico)/ [dostęp: 18.03.2016]; J.P. Kirsch, Pietro Sforza Pallavicino, CE, t. 11. 
Boska. W diecezji płockiej postawiono jednak na wciąż dominującą historię kościelną traktowaną jako immanentna część teologii ${ }^{46}$.

\section{KLASYCYZM I REHABILITACJA ROZUMU}

Podkreślałem, że program nauczania historii kościelnej był zarówno praworządny, jak i konserwatywny, ponieważ te dwie cechy nie musiały iść w parze. Omawiany kanon lektur był w każdym wymiarze ortodoksyjny, ale tylko z rzadka tradycjonalistyczny. Rekomendowane książki często stanowiły nowości wydawnicze, zostały napisane zgodnie z językowymi i stylistycznymi postulatami XVIII-wiecznych reformatorów wymowy oraz propagowały treści dotychczas niespotykane w praktyce duszpasterskiej.

Wszystkie te cechy widać szczególnie w rekomendowanych dziełach homiletycznych. W związku z popularnością tego typu literatury twórcy kanonu zamiast podkreślać ich przydatność, skupili się na nakłonieniu duchownych do samodzielnego układania kazań oraz na przekonaniu ich do wzorca stylistycznego charakteryzującego się prostotą języka, klarownością układu i rozumowością argumentów ${ }^{47}$. Lista autorów nowych kazań mówi sama za siebie. Znaleźli się w niej jedynie pisarze współcześni, pochodzący z Rzeczypospolitej i tworzący w języku polskim. Wszyscy oni wpisywali się w propagowany przez Stanisława Konarskiego wzorzec stylistyczny, a większość jest obecnie uznawana za przedstawicieli oświeceniowego kaznodziejstwa ${ }^{48}$.

Na szczególną uwagę zasługuje dwóch autorów, których dzieła zawarte w kanonie spotkały się z największą aprobatą plebanów płockich. Najbardziej rozpowszechnione były Nauki Homilie y Materye Kazań... Samuela Wysockiego. Ten praktyczny podręcznik do tworzenia kazań miał służyć duchownym do odczytywania gotowych tekstów z ambony. Niemniej książka ta mogła również zachęcać do kreatywnego kaznodziejstwa, ucząc metod konstrukcji wypowiedzi. Pod względem treści było to jednak dzieło tradycyjne, traktujące przede wszystkim o życiu Jezusa, Maryi i świętych. Z barokowego schematu wyłamywało się przede wszystkim językiem i położeniem nacisku na moralistyczne, a nie dogmatyczne wnioski ${ }^{49}$.

46 J. Kracik, Sekularyzacja pojmowania historii Kościoła w dobie Oświecenia, „Studia Theologica Varsaviensia" 1988, t. 26, nr 2, s. 253-262.

47 Rozrzadzenia..., t. 1, s. 415-417.

48 L. Grzebień, Rydzewski Wawrzyniec (1717-1765), PSB, t. 33, red. S. Kieniewicz, Wrocław-Warszawa-Kraków 1991-1992, s. 446-447; idem, Ubermanowicz Sebastian [w:] Stownik polskich teologów katolickich [dalej: SPTK], t. 4, s. 365-366; S. Bednarski, Abramowicz Adam, PSB, t. 1, red. W. Konopczyński, Kraków 1935, s. 11; J. Wy socki, Zachariaszewicz (Zacharyaszewicz) Grzegorz h. własnego, SPTK, t. 4, red. H.E. Wyczawski, Warszawa 1983, s. 498-499; A. Zakrzewski, Idee oświecenia w kazaniach polskich, Częstochowa 1986; W. Pazera, Polskie kaznodziejstwo epoki oświecenia, Częstochowa 2000.

49 J. Wy socki, Wysocki Samuel Sebastian, SPTK, t. 4, s. 482-483; W. Pazera, Polskie kaznodziejstwo epoki oświecenia, s. 78-84; J. Bąk, Wady ganione i cnoty zalecane w spuściźnie kaznodziejskiej Samuela Wysockiego, Kalisz 2002. 
Drugim najpopularniejszym autorem był jezuita Kasper Balsam stosujący bardzo prostą narrację, całkowicie poporządkowaną treści ${ }^{50}$. Jego twórczość najlepiej wpisywała się w model oświeconego katolicyzmu, propagujący kaznodziejstwo nastawione na przekazywanie ludowi idei moralnych mających zwiększyć jakość życia doczesnego. Jednocześnie propagował treści ściśle polityczne, poszerzające w znaczący sposób zakres świadomości słuchaczy. Co więcej, w kazaniach o tematyce moralnej jego argumentacja była nie tylko rozumowa i oparta na potocznym doświadczeniu, ale wprost waloryzująca rozum jako środek do dedukcji praw etycznych równy objawieniu.

Do grupy kazań starszych zakwalifikowane zostały natomiast najwybitniejsze dzieła barokowej homiletyki, które w swojej formie nie poddawały się mankamentom stylu swojej epoki ${ }^{51}$. Biskup mógł przewidywać, że rekomendowani autorzy byli znani plebanom, ponieważ $-\mathrm{z}$ dwoma wyjątkami $\left(5.4,5.7^{52}\right)$ - pisali po polsku (5.1, $\left.5.2^{53}\right)$ lub ich dzieła przetłumaczono na polski $\left(5.3,5.5,5.5,5.8^{54}\right)$.

Ten zestaw wybitnych autorów polskich uzupełniono podręcznikami kaznodziejskimi. Stanowiło to konsekwencję dbałości o samodzielność twórczą plebanów, ale trudno zrozumieć motywację podania wyłącznie autorów zagranicznych, niedrukowanych w Rzeczypospolitej oraz nieznanych w języku polskim $\left(7.1^{55}\right)$, a nawet łacińskim $\left(7.2,7.3^{56}\right)$. Trudno było się spodziewać, by plebani kupowali te książki, szczególnie że dzieło Samuela Wysockiego spełniało identyczną funkcję.

\section{MORALISTYKA I INTELEKTUALIZM}

Twórczość najpopularniejszych autorów kazań naprowadza na dwie kolejne cechy omawianego kanonu lektur: nastawienie na dobre obyczaje oraz intelektualizm. Pierwsza $z$ nich była widoczna przede wszystkim w wyłącznej reprezentacji dzieł $\mathrm{z}$ zakresu moralistyki w dziale teologii dogmatycznej. Tej ostatniej poświęcono kilka słów, wskazując przydatność do rozjaśniania „,ciemnych z siebie prawd” i polemiki $\mathrm{z}$ innowiercami, podczas gdy teologii moralnej poświęcono długi ustęp przekonujący, że jest to najważniejsza dyscyplina wiedzy, niezbędna zarówno do słuchania spowiedzi, jak i głoszenia kazań. Nakierowanie na naukę o dobrych obyczajach można uznać za rys oświeceniowy ${ }^{57}$. Ważniejsze jest jednak, że dobrane lektury należały

50 W. Pazera, Polskie kaznodziejstwo epoki oświecenia, s. 39-48; L. Grzebień, Balsam Kasper, SPTK, t. 1, red. H.E. Wyczawski, Warszawa 1981, s. 93-94; A. Zakrzewski, op. cit., passim.

${ }_{51}$ W. Pazera, Kaznodziejstwo w Polsce od początku do końca epoki baroku, Częstochowa 1999.

52 Estreicher.

53 L. Grzebień, Skarga Piotr, SPTK, t. 4, s. 84-92; H. Wyczawski, Wujek Jakub, SPTK, t. 4, s. $469-478$.

54 Estreicher, t. 16, s. 343-344; t. 2, s. 300; t. 10, s. 72; t. 6, s. 330-334.

55 W.F. Keogh, St. Charles Borromeo, CE, t. 3; N. Scheid, Vincent Houdry, CE, t. 7.

56 A.M.P. Ingold, Louis Thomassin, CE, t. 14.

57 W. Pazera, Polskie kaznodziejstwo epoki oświecenia, s. 18-25. 
do umiarkowanie rygorystycznego nurtu probabilioryzmu $\left(1.1,1.5^{58}\right)$. Ich autorzy dopuszczali rezygnację ze stosowania prawa moralnego w sytuacjach wątpliwych, ale tylko pod warunkiem, że opinia to umożliwiająca była bardziej prawdopodobna od przeciwnej ${ }^{59}$.

Intelektualizm uznaję z kolei za najistotniejszą i najbardziej oryginalną cechę kanonu lektur. Duchowni, czytając rekomendowane książki, mieli nie tyle rozwijać praktyczne umiejętności, ile nabywać teoretycznej wiedzy. W historii Kościoła położono nacisk na świadomość błędów popełnianych przez dziejopisów, skłaniającą do samodzielnego myślenia $\left(2.6^{60}\right)$, oraz na umiejętności z zakresu chronologii $\left(2.8^{61}\right)$. W katechetyce zignorowano całkowicie lokalną praktykę lektury dzieła Chleb $d u$ chowny... Jana Wujkowskiego ${ }^{62}$. Odrzucono też inne polskie dzieła, również te nakierowane na nauczanie ludu ${ }^{63}$, sugerując wyłącznie katechizm trydencki oraz erudycyjne dzieło przedstawiające prawdy wiary w kontekście dziejów Kościoła. Miało to zapewne służyć ukazaniu plebanom głębszego sensu ich pracy $\left(9.1,9.2^{64}\right)$. W liturgice polecono książki omawiające historyczną genezę i mistyczny sens ceremonii kościelnych, unaoczniające znaczenie czynności kapłańskich oraz sprzyjające odejściu od czystego rytualizmu $\left(4.1,4.2^{65}\right)$. $\mathrm{Z}$ całą mocą rewaloryzowano znaczenie samodzielnej lektury Pisma Świętego ${ }^{66}$. Polecano również komentarze biblijne pomagające znajdywać w niej dowody w sprawach ekonomicznych i politycznych oraz zwracające uwagę na literalne znacznie Pisma Świętego, bez wykrzywienia mistycznego i moralnego $\left(8.3,8.5^{67}\right)$.

58 Brakowało natomiast probabilizmu w stylu Henryka Busenbauma oraz typowego dla jansenistów rygoryzmu. J.M. Harty, Probabilism, CE, t. 12; J. Pryszmont, Historia teologii moralnej, Warszawa 1987, s. 134-136. Jednym z polecanych autorów był z kolei Alfons Maria Liguori, twórca doktryny ekwiprobabilizmu, będącej obecnie oficjalną nauką Kościoła katolickiego, J. Pryszmont, op. cit., s. $139-142$.

59 J.M. Harty, Probabilizm, CE, t. 12; J. Pryszmont, op. cit., s. 138.

60 M. Ott, Antoine Pagi, CE, t. 11.

61 J. de Ghellinck, Denis Pétau, CE, t. 11.

62 Estreicher, cz. 3, t. 22, s. 401. Dzieło to znajdowało się w 68 parafiach diecezji płockiej.

${ }_{63}$ T. Wiślicz, Jak nauczyć analfabetę? Metodologiczne problemy duszpasterstwa katolickiego w Rzeczpospolitej XVIII wieku [w:] Między barokiem a oświeceniem. Edukacja, wykształcenie, wiedza, red. S. Achremczyk, Olsztyn 2005, s. 164.

64 J. Słowiński, Katechizmy katolickie w języku polskim od XVI do XVIII wieku, Lublin 2005, s. 93-102. G. Ubaldo, Fleury Claude [w:] Stownik katechetyczny, Warszawa 2007, s. 267-269; J.P. Kirsch, Claude Fleury, CE, t. 6.

65 Estreicher; D. Dunford, Bartolommeo Gavantus, CE, t. 6.

66 Rozrzadzenia..., t. 1, s. 408.

67 W. Drum, Giovanni Stefano Menochio, CE, t. 101; F. S. Bechte1, Dom Augustin Calmet, CE, t. 3. 


\section{OŚWIECONY KATOLICYZM}

Profil ideowy kanonu lektur jest typowy dla oświeconego katolicyzmu, to znaczy wprowadza nowy styl i treści, nie wykraczając poza ramy wyznaczone przez sobór trydencki. Szczególnie symptomatyczny był cechujący całą reformę intelektualizm - przekonanie, że wiedza bezpośrednio przekłada się na moralne postępowanie, że praktyka kapłańska potrzebuje teoretycznego wyjaśnienia sensu obrzędów oraz że gwarantem skuteczności duszpasterskiej jest przede wszystkim przewaga kulturowa nad wiernymi:

[...] nadto umiejętności i nauki przyzwoitej i gruntownej po wszystkich naszych kapłanach wyciągać nam należy. Z samego wejrzenia na kapłana miałby się domyślać lud, że to jest dobrze uczony człowiek i nauczyciel prawdy... ${ }^{68}$

Ponieważ jako mały strumyk wielkiego ciężaru nie porwie i nie poniesie, tak i wasza miałka umiejętność ociężałego w nieprawościach serca zgoła nie poruszy; trzeba więc żeby jak obfita rzeka z wielu strumieni złożona była ${ }^{69}$.

Kryjąca się za tym oświeceniowa wiara w rozum mogła jednak stać w sprzeczności $\mathrm{z}$ równie oświeceniowym postulatem nauczania warstw ludowych. Autorzy programu pisanego pod opieką biskupa płockiego zakładali bowiem, że skuteczność oświecania zależy wyłącznie od kompetencji duchowieństwa. Zupełnie zignorowali kwestię metod przekazywania wiedzy. Biskupi Ignacy Massalski i Józef Kossakowski, również przedstawiciele oświeconego katolicyzmu, wyrażali postulaty wprost odwrotne ${ }^{70}$. Według obu litewskich hierarchów duchowieństwo parafialne powinno z jednej strony do minimum ograniczać wiedzę teoretyczną, a z drugiej dopasowywać poziom nauki do słuchaczy i przede wszystkim służyć praktyczną pomocą swoim parafianom. Ten ściśle utylitarny postulat jest w programie pisanym w diecezji płockiej nieobecny. Jedynym celem duchownych pozostawała troska o zbawienie wiernych.

\section{RECEPCJA KANONU LEKTUR WŚRÓD DUCHOWIEŃSTWA PARAFIALNEGO}

Plebani diecezji płockiej ewidentnie, choć skrajnie selektywnie przyjęli sugerowaną listę lektur. Pomijając dzieła niemające jednoznacznego autora, pod koniec

\footnotetext{
68 Rozrzadzenia..., s. 405.

69 Ibidem, s. 426.

70 Kaptan stuga boży y pasterz dusz czyli list xiędza plebana do xiędza brata swego zamykaiacy w Krótkim zebraniu obowiązi kaptańskie i pasterza dusz, Wilno 1793, s. 1-6; J. Kossakowski, Xiadz Pleban, Warszawa 1786; M. Ślus arska, Ku odnowie życia religijno-moralnego wiernych i poprawie ich obyczajów. Duchowieństwo diecezji wileńskiej w okresie pontyfikatu biskupa Ignacego Jakuba Massalskiego (1762-1794) a oświeceniowa reforma katolicka, „Senoji lietuvos literatūra” 2010, t. 33, s. 171-211.
} 
pontyfikatu Michała Poniatowskiego posiadano zalecane książki tylko 19. spośród 55. rekomendowanych twórców. Jednocześnie niektóre z nich znajdowały się w kilkudziesięciu parafiach, ciesząc się niespotykaną gdzie indziej popularnością.

Od ogólnej konstatacji wpływu biskupa na kulturę plebanów znacznie istotniejsza jest jednak selektywność wyboru. Duchowieństwo diecezji płockiej zakupiło wyłącznie książki dające się wykorzystać praktycznie, należące do gatunków o ugruntowanej tradycji w pracy duszpasterskiej oraz wydane w Rzeczypospolitej - najczęściej na krótko przed początkiem pontyfikatu Poniatowskiego. Zdecydowanie preferowano piśmiennictwo polskojęzyczne, a jedynymi wyjątkami były znane z seminariów łacińskie podręczniki teologii moralnej.

Plebani nie byli natomiast uprzedzeni do nowych stylów i treści, jeżeli dzieła spełniały praktyczne wymagania. Wykazywali nawet otwartość na najbardziej nietradycyjnych autorów - współczesne i zaliczane do oświeconego katolicyzmu dzieła kaznodziejskie spotkały się z największym zainteresowaniem. We wszystkich badanych parafiach zgromadzono aż 133 egzemplarze dzieł autorów polecanych w kategorii „kazania nowe”, a książki przynajmniej jednego z nich trafiły do większości plebanii. Co więcej, posiadano ich prawie dwa razy więcej niż rekomendowanych kazań starych, których znaczna część nie była używana. Wyjątkiem są tu tylko dzieła Piotra Skargi, które nie traciły na popularności.

Bardzo dobrze przyjęły się dzieła z zakresu teologii moralnej - zgromadzono aż 90 egzemplarzy. Trzeba jednak przyznać, że z szerokiej listy lektur plebani wybierali nieomal wyłącznie podręczniki seminaryjne, a spośród nich znacznie częściej znane od dawna dzieła Paula Antoine'a. Trudno więc mówić o zakupach inspirowanych wprost przez list pasterski, a raczej o zgodności tego ostatniego z tradycyjnymi potrzebami duchowieństwa. Niemniej trzeba przyznać, że popularność nowo zaordynowanego podręcznika Pierre'a Colleta wzrastała, a nawet była prawdopodobną przyczyną prawie zupełnego zignorowania rekomendowanych dzieł z zakresu teorii prawa kanonicznego. Plebanom najwidoczniej wystarczały zawarte w nim dokumenty papieskie i dość często posiadane statuty diecezjalnych i prowincjonalnych synodów.

Znacznie mniej popularne były polecane dzieła z zakresu teologii ascetycznej, których zgromadzono tylko 19 . Ponadto książki należące do tego gatunku piśmiennictwa religijnego są jedynymi znanymi plebanom, przed pontyfikatem biskupa Poniatowskiego, których popularność nie wzrosła istotnie w czasie jego trwania. Duchowni wykazali się zresztą zachowawczością, gdyż mogąc wybierać spośród siedmiu wydanych w języku polskim autorów, posiadali wyłącznie dzieła Józefa Mansiego przetłumaczone przez biskupa płockiego Andrzeja Chryzostoma Załuskiego oraz dwóch autorów bardzo popularnych w całej Rzeczypospolitej - Nicola Ruggierego i Tomasza à Kempis.

W stosunku do katechizmów ujawnił się z kolei największy tradycjonalizm duchowieństwa, łączący się z dużą samodzielnością wyborów czytelniczych. W diecezji płockiej wyjątkowo popularne było bowiem dostosowane do edukacji ludu i dzieci dzieło Chleb duchowny... Jana Stanisława Wujkowskiego. Znajdowało się w większości parafii i całkowicie zaspokajało potrzeby wynikające z pracy duszpasterskiej. 
W związku z tym sporadyczne zakupy wznowionego niedawno katechizmu rzymskiego, który nie miał przecież charakteru praktycznego, były całkowicie zrozumiałe.

Najbardziej symptomatyczne wydaje się jednak całkowite odrzucenie katechizmu historycznego Claude'a Fleury'ego, a także całej historii Kościoła, teorii liturgiki i biblistyki. Były to gatunki dotychczas niewystępujące w księgozbiorach, bardzo teoretyczne, nieprzydatne $\mathrm{w}$ pracy duszpasterskiej skierowanej do przedstawicieli kultury ludowej, niepublikowane w Rzeczypospolitej i niedostępne w polskich tłumaczeniach. Podobnie wyglądała sytuacja podręczników homiletycznych i prawniczych, których rozpowszechnienie nie przekroczyło pięciu egzemplarzy. Trudno jednak odmówić tym gatunkom praktyczności. Niechęć plebanów wynikała z popularności dzieł należących do innych kategorii, zawierających fragmenty służące układaniu kazań i rozeznaniu w prawie.

\section{WNIOSKI}

Duchowieństwo parafialne całkowicie odrzuciło książki, których rekomendacja wynikała z wiary w istotność wiedzy teoretycznej. Niezgody tej nie można jednak interpretować w kategoriach tradycjonalizmu czy niechęci do nauki. Wynikała ona raczej ze znacznie lepszej znajomości wiejskiego i małomiasteczkowego środowiska.

Co oczywiste, plebani i wikariusze spędzali większość życia w bezpośrednim kontakcie ze swoimi wiernymi, podczas gdy biskup i jego współpracownicy zjeżdżali na prowincję niezwykle rzadko. Sam Poniatowski w Płocku pojawił się tylko raz i nie dokonał samodzielnie ani jednej wizytacji parafialnej ${ }^{71}$. Plebani i wikariusze wywodzili się nie tylko ze szlachty, ale często także z mieszczaństwa i - rzadko, ale jednak - z chłopstwa, a edukację kończyli najczęściej na krótkim pobycie w seminarium ${ }^{72}$. Kulturę ludową nie tylko poznawali w toku pracy, ale też po prostu do niej należeli. Tyczy się to zresztą nawet plebanów o pochodzeniu szlacheckim, gdyż kultura religijna biedniejszych herbowych i ich poddanych była zbliżona. Ich kontakt $\mathrm{z}$ wiedzą teoretyczną był więc epizodyczny i zapewne nie wpływał na zmianę mentalności ${ }^{73}$. Członkowie administracji diecezjalnej natomiast często kończyli

${ }^{71}$ M. Grzybowski, Kościelna działalność Michała Jerzego Poniatowskiego..., s. 37.

72 H. Kołłątaj, Pamiętnik o stanie duchowieństwa katolickiego polskiego i innych wyznań w potowie XVIII wieku, Poznań 1840, s. 6-10; M. Różański, Duchowieństwo parafialne archidiakonatu uniejowskiego w XVIII wieku. Studium prozopograficzne, Łódź 2010, s. 129; ks. J. Szczepaniak, Duchowieństwo diecezji krakowskiej w XVIII wieku. Studium prozopograficzne, Kraków 2010, s. 290.

${ }_{73}$ J. Kracik, Vix venerabile..., passim; B. Rok, Mentalność duchowieństwa polskiego w XVIII wieku [w:] Studia z dziejów kultury i mentalności czasów nowożytnych, red. K. Matwijowski, B. Rok, Wrocław 1993, s. 41-57; T. Wiślicz, Religijność wiejska w Rzeczpospolitej szlacheckiej, „Barok” 2004, t. 11, s. $97-118$. 
uniwersytety i uczestniczyli w kulturze dworskiej, literacka i filozoficzna kultura słowa była elementem ich codziennego doświadczenia ${ }^{74}$.

Wszystko to powodowało, że duchowni parafialni znacznie lepiej rozumieli potrzeby i możliwości swoich wiernych. Wiedza o teologicznym sensie sakramentów, historycznej misji Kościoła czy metodach konstruowania biblijnej argumentacji nie mogła im się w żadnej mierze przydać. Zdawali sobie natomiast sprawę, że głównym odbiorcą ich nauk nie jest elita, ale chłop, małomieszczanin, a także folwarczni zarządcy i lokalna szlachta. Księża wiedzieli, że pilną potrzebą duszpasterską jest przekazanie podstawowych prawd wiary zawartych w katechizmach. Niemal każdy z nich miał więc egzemplarz Chleba duchownego..., w którym dogmaty były odniesione do życia i zobrazowane fantastycznymi, wbijającymi się w pamięć przykładami. Doświadczenie każdorocznej spowiedzi wielkanocnej przypominało o niezbędności wiedzy z zakresu teologii moralnej w rozstrzyganiu problemów obyczajowych wyłamujących się z ram katolickiej etyki. Stosowne dzieła mieli zapewne od czasów seminarium, ale reforma kongregacji dekanalnych mogła sprawić, że zaglądali do nich jeszcze częściej.

Wreszcie coniedzielny obowiązek głoszenia kazań nie pozostawiał wątpliwości, jaki styl cieszy się popularnością, a znajomość problemów parafian wpływała na priorytety w doborze tematów. Pod tymi względami propozycja administracji diecezjalnej okazała się dobrze dostosowana do potrzeb zawodowych duchowieństwa parafialnego. Rekomendowane dzieła współczesnych kaznodziejów charakteryzowały się bowiem stylem i językiem zarówno satysfakcjonującymi klasycystyczne gusta intelektualistów, jak i łatwo zrozumiałymi dla prostych słuchaczy. Poruszana tematyka, skupiająca się na obyczajach i kwestiach społecznych, była zgodna zarówno z utylitarnymi i fizjokratycznymi zainteresowaniami elity, jak i codziennymi doświadczeniami mieszkańców wsi oraz małych miast.

Wracając do postawionej we wstępie tezy, w czasie pontyfikatu Michała Poniatowskiego doszło do silnej, ale skrajnie selektywnej recepcji centralnie rekomendowanego kanonu lektur. Duchowieństwo parafialne nie było przeciwne oświeconemu katolicyzmowi, ale jego nurtom oderwanym od własnych potrzeb zawodowych. Akceptowało nowoczesny styl i aktualną tematykę, lecz odrzucało dyscypliny wiedzy niedające się wykorzystać w duszpasterstwie mas ludowych. Odrzucenie erudycyjnych części kanonu lektur można interpretować jako opór wobec procesu rozchodzenia się elitarnej i ludowej kultury religijnej. Można sobie wyobrazić, że jego przyjęcie przez plebanów i wikariuszy doprowadziłoby tylko do silniejszej separacji duchowieństwa i wiernych i nie przyniosłoby bynajmniej skutków zamierzonych przez administrację.

74 Bp Poniatowski w wieku 18 lat pojechał do Rzymu studiować, a w wieku 20 lat trafił do seminarium, ks. Żórawski był doktorem obojga praw, M. Grzybowski, Kościelna działalność Michała Jerzego Poniatowskiego..., s. 26-27 i 38. 


\section{BIBLIOGRAFIA}

\section{Źródła rękopiśmienne}

Archiwum Diecezjalne w Płocku

Wizytacja dekanatu płockiego 1774, sygn. AV 288.

Wizytacja dekanatów: Ostrołęka, Ostrów, Wąsocz, Wizna, Wyszków 1774, sygn. AV 307.

\section{Źródła drukowane}

Kapłan stuga boży y pasterz dusz czyli list xiędza plebana do xiędza brata swego zamykaiacy w Krótkim zebraniu obowiązi kapłańskie i pasterza dusz, Wilno 1793.

Kazania niektóre Księży Diecezji Płockiej z podanych co rocznie dwiema ratami w Maju i w Październiku do Kancelarji Zadwornej Biskupiej 1782. Teraz z tejże Kacelarji wydane i do druku podane 1785, bmw, 1785.

Kołłątaj H., Pamiętnik o stanie duchowieństwa katolickiego polskiego i innych wyznań w połowie XVIII wieku, Poznań 1840.

Kossakowski J., Xiądz Pleban, Warszawa 1786.

Materiaty do dziejów ziemi płockiej. Z archiwaliów diecezjalnych płockich XVIII wieku, t. 1-15, red. M.M. Grzybowski, Płock 1981-2012.

Poniatowski M.J., Rozporządzenia y pisma pasterskie za rządów J.O. Xięcia JMCI Michata Jerzego Poniatowskiego Biskupa Ptockiego do diecezyi płockiey wydane dla wygody teyże Dyecezyi zebrane, i do Druku podane, t. 1-4, Warszawa 1785.

\section{Opracowania}

\section{a) Monografie}

Bąk J., Wady ganione i cnoty zalecane w spuściźnie kaznodziejskiej Samuela Wysockiego, Kalisz 2002.

Burke P., Kultura ludowa we wczesnonowożytnej Europie, tłum. R. Pucek, M. Szczubiałka, Warszawa 2009.

Butterwick R., Polska rewolucja a kościół katolicki 1788-1792, thum. M. Ugniewski, Kraków 2012.

Giznburg C., Ser i robaki. Wizja świata pewnego młynarza z XVI w., thum. R. Kłos, Warszawa 1989.

Grzybowski M., Kościelna działalność Michała Jerzego Poniatowskiego biskupa płockiego 1773-1785, Warszawa 1983.

Kasabuła T., Ignacy Massalski biskup wileński, Lublin 1998.

Kowalski K.M., Ksieggozbiory parafialne archidiakonatu pomorskiego w XVI-XVIII [w:] Studium z dziejów kultury intelektualnej Prus Królewskich, Gdańsk 1993. 
Kracik J., Vix venerabiles. $Z$ dziejów społecznych niższego kleru parafialnego w archidiakonacie krakowskim XVII-XVIII w., Kraków 1982.

Litak S., Kościót łaciński w Polsce około 1772 roku: mapa - komentarz - indeks, Lublin 1991.

Moskal T., Biblioteki parafialne $w$ archidiakonacie sandomierskim $w$ XVIII w., Sandomierz 2005.

Pazera W., Kaznodziejstwo w Polsce od początku do końca epoki baroku, Częstochowa 1999.

Pazera W., Polskie kaznodziejstwo epoki oświecenia, Częstochowa 2000.

Pryszmont J., Historia teologii moralnej, Warszawa 1987.

Romuald G., Rozwój pojęcia historii Kościoła, Poznań 1964.

Różański M., Duchowieństwo parafialne archidiakonatu uniejowskiego w XVIII wieku. Studium prozopograficzne, Łódź 2010.

Szczepaniak J., Duchowieństwo diecezji krakowskiej w XVIII wieku. Studium prozopograficzne, Kraków 2010.

Słowiński J., Katechizmy katolickie w języku polskim od XVI do XVIII wieku, Lublin 2005.

Szady J., Księgozbiory parafialne w prepozyturze wiślickiej w drugiej połowie XVIII wieku, Lublin 2008.

Szczurowski R., Zaradzić potrzebom doczesnym i wiecznym. Idee oświecenia w Kościele katolickim w Polsce (do 1795 r.), Kraków 2014.

Zakrzewski A., Idee oświecenia w kazaniach polskich, Częstochowa 1986.

\section{b) Prace zbiorowe}

Bednarski S., Abramowicz Adam [w:] Polski Stownik Biograficzny, t. 1, red. W. Konopczyński, Kraków 1935, s. 11.

Grzebień L., Balsam Kasper [w:] Słownik polskich teologów katolickich, t. 1, red. H.E. Wyczawski, Warszawa 1981, s. 93-94.

Grzebień L., Rydzewski Wawrzyniec (1717-1765) [w:] Polski Słownik Biograficzny, t. 33, red. S. Kieniewicz, Wrocław-Warszawa-Kraków 1991-1992, s. 446-447.

Grzebień L., Skarga Piotr [w:] Stownik polskich teologów katolickich, red. H.E. Wyczawski, Warszawa 1983, t. 4, s. 84-92.

Grzebień L., Ubermanowicz Sebastian [w:] Stownik polskich teologów katolickich, t. 4, red. H.E. Wyczawski, Warszawa 1983, s. 365-366.

Obłąk T., Gabriel Paul Antoine [w:] Encyklopedia katolicka, t. 1, red. F. Gryglewicz, R. Łukaszyk, Z. Sułowski, Lublin 1973, s. 655.

Rok B., Mentalność duchowieństwa polskiego w XVIII wieku [w:] Studia z dziejów kultury i mentalności czasów nowożytnych, red. K. Matwijowski, B. Rok, Wrocław 1993, s. $41-57$.

Sołtys A., Powiernik, przyjaciel, sprzymierzeniec, ,,aktor” drugiego planu - prymas Michat Jerzy Poniatowski [w:] Pamiętniki Stanisława Augusta i ich bohaterowie, red. A. Grześkowiak-Krwawicz, Warszawa 2015, s. 151-152.

Szczurowski R., Pastoralny i literacki wzorzec kapłana doby oświecenia [w:] Historia bliższa ludziom. Prace ofiarowane Księdzu Profesorowi Janowi Kracikowi w 70. rocznice urodzin, red. R. Szczurowski, E.E. Wróbel, Kraków 2011, s. 333-346. 
Ślusarska M., Oświeceniowe modele biskupa, plebana i parafii. Kontynuacja czy zmiana tradycji? [w:] Dwór - plebania - rodzina chłopska. Szkice z dziejów wsi polskiej XVII i XVIII wieku, Warszawa 1998, s. 37-53.

Ubaldo G., Fleury Claude [w:] Stownik katechetyczny, Warszawa 2007, s. 267-269.

Wiślicz T., Jak gdyby wśród pogan lub heretyków. Polityka potrydenckiego Kościoła wobec religii ludowej i jej osobliwości w Rzeczypospolitej [w:] Staropolski oglad świata. Rzeczypospolita między okcydentalizmem a orientalizacją. Przestrzeń wyobrażeń, t. 2, red. R. Kołodziej, F. Wolański, Torun 2009, s. 31-42.

Wiślicz T., Jak nauczyć analfabetę? Metodologiczne problemy duszpasterstwa katolickiego w Rzeczpospolitej XVIII wieku [w:] Między barokiem a oświeceniem. Edukacja, wyksztatcenie, wiedza, red. S. Achremczyk, Olsztyn 2005, s. 164.

Wiślicz T., Shepherds of the Catholic Flock: Polish Parochial Clergy, Popular Religion, and the Reception of the Council of Trent [w:] Gelehrte Geistlichkeit - geistliche Gelehrte. Beiträge zur Geschichte des Bürgertums in der Frühneuzeit, t. 97: Historische Forschungen, hsg. von L. Schorn-Schütte, Berlin 2012, s. 25-52.

Wyczawski H., Wujek Jakub [w:] Słownik polskich teologów katolickich, t. 4, red. H.E. Wyczawski, Warszawa, 1983, s. 469-478.

Wy socki J., Wysocki Samuel Sebastian [w:] Stownik polskich teologów katolickich, t. 4, red. H.E. Wyczawski, Warszawa 1983, s. 482-483.

Wysocki J., Zachariaszewicz (Zacharyaszewicz) Grzegorz h. własnego [w:] Stownik polskich teologów katolickich, t. 4, red. H.E. Wyczawski, Warszawa 1983, s. 498-499.

\section{c) Artykuły w czasopismach}

Butterwick R., Między oświeceniem a katolicyzmem, czyli o katolickim oświeceniu i oświeconym katolicyzmie, „Wiek Oświecenia” 2014, t. 30, s. 11-55.

Darnton R., In Search of the Enlightenment: Recent Attempts to Create a Social History of Ideas, ,The Journal of Modern History” 1971, t. 43, nr 1, s. 113-132.

Główka D., Księgozbiory duchowieństwa płockiego w XVIII wieku, „Kwartalnik Historyczny" 1995, t. 52, nr 2, s. 18-19.

Grzybowski M., Formacja intelektualna i moralna duchowieństwa diecezji płockiej w czasach rząów bp M.H. Poniatowskiego (1773-1785), „Studia Płockie” 1976, t. 4, s. $77-$ 100 .

Grzybowski M., Reforma studiów seminaryjnych $w$ diecezji płockiej biskupa Michała Jerzego Poniatowskiego (1773-1785), „Studia Płockie” 1973, t. 1, nr 175-193.

Grzybowski M., Życie religijno-moralne $w$ diecezji płockiej $w$ czasach rząów biskupa M.J. Poniatowskiego (1773-1785), „Studia Płockie” 1976, t. 4, s. 101-144.

Kracik J., Biblioteka parafialna a prywatne ksiegozbiory duchowieństwa. Dekanat Nowa Góra w XVII-XVIII wieku, „Archiwa, Biblioteki i Muzea Kościelne” 1976, t. 32, s. 249271.

Kracik J., Ewangelicznie i rozumnie. Oświecenie katolickie, „Znak” 1992, nr 451, s. 57-69.

Kracik J., Sekularyzacja pojmowania historii Kościoła $w$ dobie Oświecenia, „Studia Theologica Varsaviensia” 1988, t. 26, nr 2, s. 253-262.

Ślusarska M., Ku odnowie życia religijno-moralnego wiernych i poprawie ich obyczajów. Duchowieństwo diecezji wileńskiej w okresie pontyfikatu biskupa Ignacego Ja- 
kuba Massalskiego (1762-1794) a oświeceniowa reforma katolicka, „Senoji lietuvos literatūra" 2010, t. 33, s. 171-211.

Wiślicz T., Religijność wiejska w Rzeczpospolitej szlacheckiej, „Barok” 2004, t. 11, s. $97-$ 118.

Witecki S., Oświecony katolicyzm trydencki. Księgozbiory duchowieństwa parafialnego diecezji płockiej w okresie pontyfikatu bp. Michała Jerzego Poniatowskiego, „Wiek Oświecenia" [w druku].

\section{d) Materiały internetowe}

Bibliografia Polska Karola Estreichera, cz. 3, t. 1-36, http://www.estreicher.uj.edu.pl/staropolska/ [dostęp: 18.03.2016].

Catholic Encyclopedia, New York, https://en.wikisource.org/wiki/Catholic_Encyclopedia_ (1913) [dostęp: 18.03.2016].

Bechtel F.S., Dom Augustin Calmet, CE, t. 3.

Drum W., Giovanni Stefano Menochio, CE, t. 10.

Dunford D., Bartolommeo Gavantus, CE, t. 6.

Ghellinck J. de, Denis Pétau, CE, t. 11.

Harty J.M., Probabilism, CE. t. 12.

Ingold A.M.P., Louis Thomassin, CE, t. 14.

Keogh W.F., St. Charles Borromeo, CE, t. 3.

Kirsch J.P., Claude Fleury, CE, t. 6.

Kirsch J.P., Pietro Sforza Pallavicino, CE, t. 11.

McMahon A.L., Alexander Natalis, CE, t. 1.

Ott M., Antoine Pagi, CE, t. 11.

Scheid N., Vincent Houdry, CE, t. 7.

Weber N.A., Giovanni Lorenzo Berti, CE, t. 2.

Windsor Fanning W.H., Vitus Pichler, CE, t. 12.

Vannini F., Mario Guarnacci [w:] Dizionario Biografico degli Italiani, t. 60, 2003, http:// www.treccani.it/enciclopedia/mario-guarnacci_(Dizionario-Biografico)/ [dostęp: 18.03. 16].

Zielińska Z., Michał Jerzy Poniatowski h. Ciołek [w:] Polski Słownik Biograficzny, n.d., t. 17, http://www.ipsb.nina.gov.pl/index.php/a/michal-jerzy-poniatowski-h-ciolek, [dostęp: 8.12.2016]. 


\section{ANEKS}

\begin{tabular}{|c|c|c|c|c|}
\hline LP. & AUTOR & $\begin{array}{c}\text { LATA } \\
\dot{\text { ZYCIA }}\end{array}$ & $\begin{array}{l}\text { DRUK } \\
\text { W RP }\end{array}$ & L. EGZ. \\
\hline \multicolumn{4}{|c|}{ 1. TEOLOGIA DOMATYCZNA } & 90 \\
\hline 1.1. & $\begin{array}{l}\text { Pierre Collet } \\
\text { Institutiones Theologicae quas ad usum } \\
\text { Seminariorum... (27) } \\
\text { Tractatus theologicus de impedimentis mat- } \\
\text { rimony... (1) }\end{array}$ & $1693-1770$ & tak & 29 \\
\hline 1.2 . & $\begin{array}{l}\text { Paul Gabriel Antoine } \\
\text { Theologia universa, matrimonye, dogmatica } \\
\text { et moralis... (43) } \\
\text { Theologia moralis universa... (11) }\end{array}$ & $1679-1743$ & tak & 54 \\
\hline 1.3 . & $\begin{array}{l}\text { Pierre Annat } \\
\text { Apparatus Ad Positivam Theologiam } \\
\text { Methodicus... }\end{array}$ & $1638-1715$ & nie & 0 \\
\hline 1.4. & $\begin{array}{l}\text { Alfons Maria Liguori } \\
\text { Theologia moralis... }\end{array}$ & $1696-1787$ & nie & 0 \\
\hline 1.5 . & $\begin{array}{l}\text { Johann Reuter } \\
\text { Theologia moralis quadripartita... (2) } \\
\text { Neo-confessarius practice instructus... (1) }\end{array}$ & zm. 1762 & nie & 3 \\
\hline 1.6. & $\begin{array}{l}\text { Edmund Voit } \\
\text { Theologia moralis... }\end{array}$ & $1707-1780$ & nie & 4 \\
\hline 1.7 . & $\begin{array}{l}\text { Charles Witasse } \\
\text { Tractatus theologici... }\end{array}$ & $1660-1716$ & nie & 0 \\
\hline 1.8. & $\begin{array}{l}\text { Carlo Sardagna } \\
\text { Theologia Dogmatico-Polemica... }\end{array}$ & $1731-1775$ & nie & 0 \\
\hline 1.9 . & $\begin{array}{l}\text { Bonaventura Leonardelli } \\
\text { Decisiones Practicae Casuum } \\
\text { Conscientiae... }\end{array}$ & $1673-1757$ & nie & 0 \\
\hline \multicolumn{4}{|c|}{$2 . \quad$ HISTORIA KOŚCIOLA } & $\mathbf{0}$ \\
\hline 2.1 . & $\begin{array}{l}\text { Giovanni Lorenzo Berti } \\
\text { Ecclesiastica historia breviarium... }\end{array}$ & $1696-1766$ & nie & 0 \\
\hline 2.2 . & $\begin{array}{l}\text { Jean Cabassut } \\
\text { Notitia Conciliorum Sanctae Ecclesiae... }\end{array}$ & $1604-1685$ & nie & 0 \\
\hline 2.3 . & $\begin{array}{l}\text { Alexandro Natalis } \\
\text { Historia ecclesiastica... }\end{array}$ & $1639-1724$ & nie & 0 \\
\hline
\end{tabular}




\begin{tabular}{|c|c|c|c|c|}
\hline 2.4 . & $\begin{array}{l}\text { Alphonso Chacón } \\
\text { Vitae, et res gestae pontificum romanorum... }\end{array}$ & $1530-1599$ & nie & 0 \\
\hline 2.5 . & $\begin{array}{l}\text { Mario Guarnacci } \\
\text { Vitae, et res gestae pontificum romanorum... }\end{array}$ & $1701-1785$ & nie & 0 \\
\hline 2.6. & $\begin{array}{l}\text { Antoine Pagi } \\
\text { Critica Historico-Chronologica... }\end{array}$ & $1624-1699$ & nie & 0 \\
\hline 2.7 . & $\begin{array}{l}\text { Pietro Sforza Pallavicino } \\
\text { Vera Concilii tridentini historia... }\end{array}$ & $1607-1667$ & nie & 0 \\
\hline 2.8 . & $\begin{array}{l}\text { Denis Pétau } \\
\text { Rationarium Temporum... }\end{array}$ & $1583-1652$ & nie & 0 \\
\hline 3. & PRAWO KANONICZNE & & & 28 \\
\hline 3.1 . & $\begin{array}{l}\text { Vitus Pichler } \\
\text { Candidatus abbreviatus jurisprudetiae } \\
\text { sacrae, hoc est Iuris Canonici... }\end{array}$ & $1670-1736$ & tak & 1 \\
\hline 3.2 . & $\begin{array}{l}\text { Paweł Piasecki } \\
\text { Praxis episcopalis... }\end{array}$ & $1570-1649$ & tak & 1 \\
\hline 3.3 . & \multicolumn{3}{|c|}{ Constitutiones Synodorum Metropolitanae Ecclesiae Gnesnensis... } & 3 \\
\hline 3.4 . & \multicolumn{3}{|c|}{ Konstytucje nieokreślonych synodów diecezji płockiej } & 22 \\
\hline 3.5 . & $\begin{array}{l}\text { Anaklet Reiffenstuel } \\
\text { Ius canonicum universum... }\end{array}$ & $1641-1703$ & nie & 0 \\
\hline $\begin{array}{l}3.6 . \\
3.7 .\end{array}$ & $\begin{array}{l}\text { Benedykt XIV } \\
\text { De Synodo Dioecesana... } \\
\text { Institutionum ecclesiasticarum... }\end{array}$ & $1675-1758$ & nie & 0 \\
\hline \multicolumn{4}{|c|}{ LITURGIKA (z wylączeniem ksiąg liturgicznych) } & $\mathbf{0}$ \\
\hline 4.1. & $\begin{array}{l}\text { Bartholomeo Gavanto } \\
\text { Compendium breve Thesauri Sacrorum } \\
\text { Rituum... }\end{array}$ & $1569-1638$ & tak & 0 \\
\hline 4.2 . & $\begin{array}{l}\text { Gaetano Maria Merat } \\
\text { Novae observationes et additions... }\end{array}$ & $\begin{array}{l}\text { brak } \\
\text { danych }\end{array}$ & nie & 0 \\
\hline 4.3. & $\begin{array}{l}\text { Benedykt XIV } \\
\text { Rituale romanum, caeremoniale episcopo- } \\
\text { rum ac pontificale romanum... }\end{array}$ & $1675-1758$ & nie & 0 \\
\hline 4.4 . & $\begin{array}{l}\text { Carlo Borromeo } \\
\text { De praecipius clericorum, confessariorum, } \\
\text { concionatorum et parochianorum officiis } \\
\text { enchiridion }\end{array}$ & $1538-1584$ & tak & 0 \\
\hline \multicolumn{4}{|c|}{ KAZANIA STARE } & 71 \\
\hline 5.1. & Piotr Skarga & $1536-1612$ & tak & 33 \\
\hline 5.2. & Jakub Wujek & $1541-1597$ & tak & 10 \\
\hline 5.3. & Paolo Segneri & $1624-1694$ & tak & 19 \\
\hline 5.4 . & Claude de Lingendes & $1591-1660$ & nie & 0 \\
\hline
\end{tabular}




\begin{tabular}{|c|c|c|c|c|}
\hline 5.5 . & Louis Bourdaloue & $1632-1704$ & tak & 6 \\
\hline 5.6 . & Charles de la Rue & zm. 1643 & tak & 1 \\
\hline 5.7. & Jacobus Tirinus & $1580-1636$ & nie & 0 \\
\hline 5.8. & Luis de Granada & $1504-1588$ & tak & 2 \\
\hline \multicolumn{4}{|c|}{ KAZANIA NOWE } & 133 \\
\hline 6.1. & Wawrzyniec Rydzewski & $1716-1765$ & tak & 22 \\
\hline 6.2 . & Adam Abramowicz & $1710-1766$ & tak & 3 \\
\hline 6.3 . & Kasper Balsam & $1716-1759$ & tak & 27 \\
\hline 6.4 . & Sebastian Ubermanowicz & $1698-1764$ & tak & 8 \\
\hline 6.5 . & Samuel Wysocki & $1706-1771$ & tak & 50 \\
\hline 6.6. & Sebastian Lachowski & $1731-1794$ & tak & 10 \\
\hline 6.7 . & Grzegorz Zachariasiewicz & $1740-1814$ & tak & 13 \\
\hline \multicolumn{4}{|c|}{ PODRĘCZNIKI KAZNODZIEJSKIE } & 2 \\
\hline 7.1. & $\begin{array}{l}\text { Louis Thomassin } \\
\text { La methode d'étudier et d'enseigner chre- } \\
\text { tiennement... }\end{array}$ & $1631-1729$ & nie & 2 \\
\hline 7.2 . & $\begin{array}{l}\text { Carlo Borromeo } \\
\text { Instructiones praedicationis verbi Dei et } \\
\text { confessariorum... }\end{array}$ & $1538-1584$ & nie & 0 \\
\hline 7.3 . & $\begin{array}{l}\text { Vincent Houdry } \\
\text { Bibliotheca concionatoria ... complectens } \\
\text { panegyricas orationes Sanctorum... }\end{array}$ & $1631-1729$ & nie & 2 \\
\hline 8. & \multicolumn{3}{|l|}{ BIBLISTYKA } & 89 \\
\hline 8.1. & \multicolumn{3}{|l|}{ Biblia (różne wydania) } & 89 \\
\hline 8.2 . & \multicolumn{3}{|l|}{ Konkordancja biblijna } & 0 \\
\hline 8.3 . & $\begin{array}{l}\text { Giovanni Stefano Menochio } \\
\text { Commentarii Totius Sacrae Scripturae... }\end{array}$ & $1575-1655$ & nie & 0 \\
\hline 8.4 . & $\begin{array}{l}\text { Jacobus Tirinus } \\
\text { In S. Scripturam commentarius duobus } \\
\text { tomis comprehensus... }\end{array}$ & $1580-1636$ & nie & 0 \\
\hline 8.5 . & $\begin{array}{l}\text { Antoine Augustin Calmet } \\
\text { Commentarium Literale In Omnes Ac } \\
\text { Singulos Tum Veteris Cum Novi Testamenti } \\
\text { Libros }\end{array}$ & $1672-1757$ & nie & 0 \\
\hline 9. & \multicolumn{3}{|c|}{ KATECHIZMY (PODRĘCZNIKI DLA SPOWIEDNIKÓW) } & 9 \\
\hline 9.1. & \multicolumn{3}{|c|}{ Katechizm rzymski (wydanie nieokreślone) } & 8 \\
\hline 9.2 & $\begin{array}{l}\text { Claude Fleury } \\
\text { Catechisme historique... }\end{array}$ & $1640-1723$ & tak & 0 \\
\hline
\end{tabular}




\begin{tabular}{|c|c|c|c|c|}
\hline 9.3 . & $\begin{array}{l}\text { Benedykt XIV } \\
\text { Thesaurus resolutionum Sacrae } \\
\text { Congregationis Concilii... albo Casus con- } \\
\text { scientiae... }\end{array}$ & $1675-1758$ & tak & 2 \\
\hline 9.4 . & $\begin{array}{l}\text { Jean Pontas } \\
\text { Dictionarium casuum conscientiae... }\end{array}$ & $1638-1728$ & nie & 1 \\
\hline \multicolumn{4}{|c|}{ TEOLOGIA ASCETYCZNA } & 19 \\
\hline 10.1 . & $\begin{array}{l}\text { Vincent Contenson } \\
\text { Theologia mentis et cordis... }\end{array}$ & $1641-1674$ & nie & 0 \\
\hline 10.2 . & Roberto Bellarmino & $1542-1621$ & tak & 00 \\
\hline 10.3 . & $\begin{array}{l}\text { François de Sales } \\
\text { Droga do życia pobożnego }\end{array}$ & $1567-1622$ & tak & 0 \\
\hline 10.4 . & $\begin{array}{l}\text { Lorenzo Scupoli } \\
\text { Woyna Duchowna Albo Nauka do doskona- } \\
\text { tego zwycięstwa... }\end{array}$ & $1530-1610$ & tak & 0 \\
\hline 10.5 . & $\begin{array}{l}\text { Thomas à Kempis } \\
\text { O naśladowaniu Chrystusa Pana... }\end{array}$ & $1380-1471$ & tak & 8 \\
\hline 10.6 . & $\begin{array}{l}\text { Nicola de Ruggiero } \\
\text { Medytacje dla oczyszczenia y poprawienia } \\
\dot{z ̇ y c i a ~ K a p t a n ́ s k i e g o . . .}\end{array}$ & $\begin{array}{l}\text { brak } \\
\text { danych }\end{array}$ & tak & 3 \\
\hline 10.7 . & $\begin{array}{l}\text { Giuseppe Mansi } \\
\text { Pamiatka pasterskiego affektu... }\end{array}$ & $1658-1720$ & tak & 8 \\
\hline 10.8 . & $\begin{array}{l}\text { Jean Babtiste Massillon } \\
\text { Mowy Xiędza M. Massiliona Biskupa de } \\
\text { Ciermont... }\end{array}$ & $1663-1742$ & tak & 0 \\
\hline
\end{tabular}

